\title{
Factors associated with mental health of high-school students in the Islamic Republic of Iran
}

Katayoun Bakhteyar ${ }^{1}$, Fatemeh Bastami ${ }^{2}$, Farzad Ebrahimzadeh ${ }^{3}$, Mohammad Almasian ${ }^{4}$, Reza Hosseinabadi ${ }^{5}$ and Ali Farhadi ${ }^{6}$

${ }^{1}$ Social Determinants of Health Research Center, Lorestan University of Medical Sciences, Khorramabad, Islamic Republic of Iran. ${ }^{2}$ Health Education and Health Promotion, Department of Health Education and Promotion, Faculty of Health, Isfahan University of Medical Sciences, Isfahan, Islamic Republic of Iran. ${ }^{3}$ Department of Public Health, Faculty of Health and Nutrition, Lorestan University of Medical Sciences, Khorramabad, Islamic Republic of Iran. ${ }^{4}$ Department of English Language, Faculty of Medicine, Lorestan University of Medical Sciences, Khorramabad, Islamic Republic of Iran. ${ }^{5}$ Department of Nursing, Faculty of Nursing and Midwifery, Lorestan University of Medical Sciences, Khorramabad, Islamic Republic of Iran. ${ }^{6}$ Department of Social Medicine, Lorestan University of Medical Sciences, Islamic Republic of Iran (Correspondence to: Ali Farhadi: Farhady.Ali@gmail.com).

\begin{abstract}
Background: Mental disorders of adulthood can be traced to childhood and adolescent disorders so attention to the mental health of young people is important.

Objectives: We aimed to determine the mental health status of high-school students in Khorramabad and the factors that may affect it.

Methods: This cross-sectional study included 1202 high-school students in Khorramabad in the 2015-2016 academic year. Students were selected using stratified and multistage cluster random sampling. Data were collected on sociodemographic characteristics of the students, and the General Health Questionnaire (GHQ-28) was used to assess symptoms of mental disorders. Logistic regression analysis was used to evaluate the relationship between the presence of symptoms of mental disorder and sociodemographic characteristics.

Results: The mean age of the students was 16.1 (SD 0.9) years and 52.7\% were girls. Overall, 481 (40\%) students (34\% of males, $46 \%$ of females) had symptoms of mental disorders. Most had mild symptoms; $5 \%$ had severe symptoms. Symptoms of anxiety, depression and social impairment were seen in $40 \%, 33 \%$ and $32 \%$ of the students respectively; significantly more girls had these symptoms $(\mathrm{P}<0.05)$. Female students, those in higher school grades, and those whose fathers were unemployed and mothers were housewives were significantly more likely to have symptoms of mental disorders $(\mathrm{P}<$ 0.05).
\end{abstract}

Conclusions: This study found a high prevalence of symptoms associated with mental disorders in the adolescents in Khorramabad. Counselling centres in schools are needed to offer psychiatric counselling services to students and to implement regular mental health training programmes.

Keywords: Mental health, adolescents, high-school students, anxiety, depression, Iran.

Citation: Bakhteyar K; Bastami F; Ebrahimzadeh F; Almasian M; Hosseinabadi R; Farhadi A. Factors associated with the mental health of high-school students in the Islamic Republic of Iran. East Mediterr Health J. 2018;24(4):368-376. https://doi.org/10.26719/2018.24.4.368

Received: 27/10/15; accepted: 29/03/17

Copyright (c) World Health Organization (WHO) 2018. Some rights reserved. This work is available under the CC BY-NC-SA 3.o IGO license (https:// creativecommons.org/licenses/by-nc-sa/3.o/igo).

\section{Introduction}

Solid evidence shows that mental disorders of adulthood can be traced to childhood and adolescent disorders, and that preventive and treatment interventions can stop their development in childhood, adolescence and adulthood (1).

Given that the years of adolescence are a very formative period, vulnerabilities to mental disorders can seriously affect the abilities and life of the individual. Therefore, it is especially important to pay attention to the material and psychological needs of young people. In addition to the efforts we make to keep our children in good health, and the arrangements we make for their education, we need to better understand factors that can harm their mental and psychological wellbeing so that appropriate solutions can be found to prevent and relieve mental disorders and problems. Knowing the prevalence of these disorders and psychopathologies in adolescents is a first step to tackling them (2).

Several studies on the prevalence of symptoms associated with mental disorders have been conducted in the Islamic Republic of Iran using various instruments, and these indicate a high prevalence of such symptoms. A study in rural and urban populations over 15 years of age in the cities of Borujen and Shahrekord, using the Symptom Checklist-90-R (SCL-90-R) test reported a prevalence of $18.3 \%$ of symptoms associated with mental disorders (3). Another study of female students in Urmia reported a prevalence of depression of $68.1 \%$ as assessed with the Beck Depression Inventory (4). The prevalence of symptoms associated with mental disorders was reported to be $51.8 \%$ in students at Mazandaran University of Medical Sciences using the SCL-90-R test (5); 37.2\% among male and female school students in Kurdistan, as assessed with the Child Symptom Inventory (6); 33\% among Iranian university students using the General Health Questionnaire (GHQ-28) questionnaire (7); and 
40.7\% in students in Bushehr also using the GHQ-28 instrument (8). A study conducted on adults older than 18 years in Kashan reported a prevalence of symptoms associated with mental disorders of $29.2 \%$ (9), while in the Iranian National Health and Disease Survey Project, the prevalence in individuals older than 15 years was $21 \%$, with the highest prevalence reported in the Chaharmahal and Bakhtiari province (39.1\%) (10). In addition, $60.2 \%$ of students in Hamadan scored more than 23 on the general scale of GHQ-28 (11). In this instrument, the cut-off point for determining whether individuals are at risk of mental disorders is 23 and higher.

To prevent the occurrence of mental disorders, it is necessary to determine the symptoms of mental problems among students. The availability of such information can help improve mental health programmes. Therefore, given the aforementioned considerations and the increase in the prevalence of symptoms associated with mental disorders in society as a whole and especially among the adolescents and young people (3-8), and also the absence of previous studies conducted with appropriate instruments in Khorramabad, this study aimed to determine the prevalence of symptoms associated with mental disorders among high-school students in Khorramabad, Islamic Republic of Iran, using the GHQ-28. This standardized questionnaire can be used as a preliminary screening device and screens students for mild mental symptoms such as depression, anxiety, somatic symptoms and social functioning.

\section{Methods}

\section{Study design, sample and setting}

The sample in this cross-sectional study was drawn from all high-school students in the city of Khorramabad, in the west of the Islamic Republic of Iran, during the academic year of 2015-2016. Students were selected through stratified sampling and multistage cluster random sampling as follows: the high schools were divided into 2 strata - state and nonprofit schools. Nonprofit schools are run by the government but parents pay an annual fee in return for which schools provide the students with welfare facilities and services. Students of these schools are generally of a higher social and economic status than those of public schools. Then, each stratum was divided into substrata of girls' and boys' high schools. In the next stage, clusters were chosen from the schools. Each cluster consisted of 3 strata, which were the school grades. Then, new clusters, i.e. the classes, were selected from each grade. Finally, students were selected from each class by systematic sampling.

The initial sample size was estimated using the formula: $\mathrm{n}=\mathrm{z} 2(1-\alpha / 2) \times \mathrm{p}(1-\mathrm{p}) / \mathrm{d} 2$, where $\alpha=0.05, \mathrm{z}(1-\alpha / 2)$ $=1.96, \mathrm{p}=0.31$ and $\mathrm{d}=0.03$; this was based on a pilot study with 100 participants The calculated sample size obtained was 913 individuals. Given the design effect, the final sample size was increased by $50 \%$ to 1369 individuals. However, because of drop-outs, 1202 students, 569 boys and 633 girls, participated in the study.

\section{Questionnaire and data collection}

Data were collected with a 2-part questionnaire. The first part included demographic, educational and family characteristics of the students, and the second part included the GHQ-28 questionnaire as standardized for the Islamic Republic of Iran (12). The standardized GHQ-28 questionnaire is a self-completed questionnaire with 28 items (4 subscales with 7 questions in each subscale). The subscales in the questionnaire include physical symptoms, anxiety symptoms, social impairment, and depression symptoms. To confirm the validity of the questionnaire, content validity was assessed by 5 specialists in the field (2 psychologists, a biostatistician, a specialist in health education and a psychiatrist). The reliability of the questionnaire was determined using the Cronbach alpha test measured for 100 students whose characteristics were similar to the target group. Cronbach alpha values were: 0.747 for somatic complaints, 0.780 for anxiety and sleep disorders, 0.803 for social impairment, 0.882 for depression and 0.918 for the whole scale. The reliability of the questionnaire has been reported as $80 \%$ and the mean sensitivity as $84 \%$ and specificity as $82 \%(12,13)$. The reliability of the GHQ questionnaire has also been reported as $80 \%$ in studies in the Islamic Republic of Iran $(7,8,11,14)$.

A score was given for each question using a 4-point Likert scale with the scores of o to 3 . The scores were added to obtain the score for each criterion and finally the total mental health score was obtained by adding the scores of the criteria. The cut-off points in the questionnaire based on Iranian norms are as follows: the cut-off point for susceptible individuals was set at $\geq 23$ for the total scale, and $\geq 7$ for any of the subscales (15).

\section{Data analysis}

Data were coded and then analysed using SPSS, version 15. Descriptive statistics were used to classify the data and determine the prevalence of symptoms associated with mental disorders. The results are presented as frequencies, and mean and standard deviation (SD). Logistic regression analysis was used to determine the association between sociodemographic characteristics and symptoms associated with mental disorders. Variables with a $P$-value $<0.25$ in the bivariate analysis (chi-squared test and independent t-test) were included in the logistic regression analysis. To avoid multicollinearity between the independent variables, type of school and father's and mother's education were excluded.

\section{Ethical considerations}

The study was approved by the University Ethics Committee of the Lorestan University of Medical Sciences (No. IR.LUMS. REC.1392.1184). Authorization of school officials was obtained to conduct the study. The objectives of the study were explained to the participants and they were told that their information would remain confidential. Written consent was obtained from the students and their families to participate in the study. The students' participation in the study was optional and, if requested, the students and their families were informed of the results of the test. 


\section{Results}

Table 1 shows the demographic and background characteristics of the students. Just over half were girls, 633 (52.7\%). The ages of the students ranged from 14 to 18 years with a mean age of 16.1 (SD 0.9) years. The greatest proportion $(40.4 \%)$ were sophomores (2nd year of high school). In terms of academic stream, 297 (24.7\%) were in the general studies stream, $261(21.7 \%)$ in mathematical sciences, 304 (25.3\%) in empirical sciences, and 340 $(28.3 \%)$ in human sciences. The education levels of most of the students' mothers 1057 (87.9\%) and fathers 888 (73.9\%) were below university. Regarding parental profession, 504 (41.9\%) of the fathers were government employees and 445 (37.9\%) were self-employed while 964 (80.2\%) of the mothers were housewives.

Table 2 shows the severity of symptoms associated with mental disorders in the students by sex. Overall, $481(40 \%)$ of the students had symptoms associated with mental disorders - including 193 (33.9\%) boys and 288 $(45.5 \%)$ girls. Regarding the severity of the symptoms associated with mental disorders, $361(30 \%)$ had mild symptoms, 95 (7.9\%) had moderate symptoms, and 25 (2.1\%) showed severe symptoms.

Table 3 shows the types of symptoms associated with mental disorders in the high-school students by sex. About $40 \%$ of the students had symptoms associated with anxiety, while $33 \%$ had symptoms of depression and $32 \%$ showed symptoms of social impairment. Overall, the mean score was highest for anxiety, 6.1 (SD 4.2). Significantly more girls showed symptoms of depression, anxiety and somatic complaints $(P<0.001)$ and social impairment $(P=0.028)$. They also had higher mean scores for all types of symptom.

Table 4 shows the results of the bivariate analysis of sociodemographic characteristics associated with symptoms of mental disorders. Age, sex, grade, academic stream and father's and mother's occupation had $P$-values $<0.25$ and were entered in the regression analysis.

Table 5 shows the results of the logistic regression analysis.Adjusting for the effects of the other confounding variables, the odds of having symptoms associated with mental disorders were $58 \%$ greater in girls than boys $(P<0.001,95 \%$ CI: 1.23-2.02). With regard to stream, the odds of having symptoms associated with mental disorders were $46 \%$ lower in students in empirical sciences than those in general and human sciences $(P<0.001,95 \%$ CI: 0.39-0.76). Students whose fathers were government employees and worker/farmers were, respectively, $41 \%$ $(P=0.035)$ and 60\% $(P=0.001)$ less likely to be susceptible to mental disorders than those whose fathers were unemployed. Moreover, students whose mothers were government employees were $49 \%$ less likely to have symptoms of mental disorders compared to those whose mothers were housewives $(P=0.01)$.

As regards grade and mental health status, 2nd- and 3rd-year students respectively were $2.40(P=0.001)$ and $2.55(P=0.017)$ times more likely to have symptoms of
Table 1 Characteristics of the high-school students in

\section{Khorramabad $(n=1202)$}

\begin{tabular}{|c|c|c|}
\hline Characteristic & No. & $\%$ \\
\hline \multicolumn{3}{|l|}{ Sex } \\
\hline Male & 569 & 47.3 \\
\hline Female & 633 & 52.7 \\
\hline \multicolumn{3}{|l|}{ Type of school } \\
\hline State & 808 & 67.2 \\
\hline Nonprofit & 394 & 32.8 \\
\hline \multicolumn{3}{|l|}{ Age (years) } \\
\hline 14 & 44 & 3.7 \\
\hline 15 & 259 & 21.6 \\
\hline 16 & 468 & 38.9 \\
\hline 17 & 416 & 34.6 \\
\hline 18 & 15 & 1.2 \\
\hline \multicolumn{3}{|l|}{ Grade } \\
\hline 1st (freshman) & 297 & 24.7 \\
\hline 2nd (sophomore) & 486 & 40.4 \\
\hline 3rd (junior) & 419 & 34.9 \\
\hline \multicolumn{3}{|l|}{ Academic stream } \\
\hline General studies & 297 & 24.7 \\
\hline Mathematical sciences & 261 & 21.7 \\
\hline Empirical sciences & 304 & 25.3 \\
\hline Human sciences & 340 & 28.3 \\
\hline \multicolumn{3}{|l|}{ Father's occupation } \\
\hline Unemployed & 95 & 7.9 \\
\hline Government employee & 504 & 41.9 \\
\hline Manual labourer or farmer & 148 & 12.3 \\
\hline Self-employed & 455 & 37.9 \\
\hline \multicolumn{3}{|l|}{ Father's education } \\
\hline Illiterate & 157 & 13.1 \\
\hline $\begin{array}{l}\text { Primary school or junior high } \\
\text { school }\end{array}$ & 335 & 27.9 \\
\hline High school & 396 & 32.9 \\
\hline University & 314 & 26.1 \\
\hline \multicolumn{3}{|l|}{ Mother's occupation } \\
\hline Housewife & 964 & 80.2 \\
\hline Government employee & 143 & 11.9 \\
\hline Worker or farmer & 24 & 2.0 \\
\hline Self-employed & 71 & 5.9 \\
\hline \multicolumn{3}{|l|}{ Mother's education } \\
\hline Illiterate & 230 & 19.1 \\
\hline $\begin{array}{l}\text { Primary school or junior high } \\
\text { school }\end{array}$ & 457 & 38.0 \\
\hline High school & 370 & 30.8 \\
\hline University & 145 & 12.1 \\
\hline
\end{tabular}

mental disorders than 1st-year students. No significant relationships were found between age and symptoms of mental disorders $(P=0.087)$. 
Table 2 Severity of symptoms associated with mental disorders in high-school students in Khorramabad by sex

\begin{tabular}{|c|c|c|c|c|c|}
\hline \multirow[t]{3}{*}{ Sex } & \multicolumn{4}{|c|}{ Severity of symptoms associated with mental disorders } & \multirow[t]{3}{*}{ P-value } \\
\hline & No symptoms & Mild & Moderate & Severe & \\
\hline & No. (\%) & No. (\%) & No. (\%) & No. (\%) & \\
\hline Male $(n=569)$ & $376(66.1)$ & $150(26.3)$ & $34(6.0)$ & $9(1.6)$ & $<0.001$ \\
\hline Female $(n=633)$ & $345(54.5)$ & $211(33.4)$ & $61(9.6)$ & $16(2.5)$ & \\
\hline Total $(n=1202)$ & $721(60.0)$ & $361(30.0)$ & 95 (7.9) & $25(2.1)$ & \\
\hline
\end{tabular}

\section{Discussion}

Our study showed that $40 \%$ of the students had symptoms associated with mental disorders according to the GHQ-28 questionnaire, $34 \%$ of the boys and $45 \%$ of the girls. Our results are in line other studies conducted in the Islamic Republic of Iran using the same instrument (GHQ-28). A meta-analysis of Iranian university students demonstrated that $33 \%$ showed symptoms associated with mental disorders (7), while the study on the students in Bushehr found a prevalence of $40.7 \%$ for symptoms associated with mental disorders (8). In the study in Hamadan, $60.2 \%$ of the students were predisposed to mental disorders (11). The Iranian National Health and Disease Survey Project, which determined the prevalence of cases suspected of mental disorders among individuals older than 15 years, reported that the highest prevalence of such disorders was $39.1 \%$ which was observed in Chahrmahal and Bakhtiari Province (10), which is also consistent with the results of our study.

On the other hand, in a study on high-school students in Rafsanjan, using the SCL-90-R questionnaire, the prevalence of symptoms associated with mental disorders was $16.6 \%$ (15). The results of a study in Kashan on people over 18 years using the GHQ-28 questionnaire, which was performed by interview, found a prevalence of $29.2 \%$ of suspected of mental disorders (9). In addition, a national epidemiological survey on 25180 Iranian individuals older than 18 years reported that $10.81 \%$ of the respondents were suspected of having mental disorders (16). This study used the Mental Disorders - IV Criteria as the instrument, which was completed in structured interviews with clinical psychologists.

Some of the differences in the prevalence of symptoms associated with mental disorder between the various studies, including ours, may be due to the different tools and methods of data collection used. The GHQ-
28 questionnaire is a self-administered questionnaire in which the participant reads the questions personally and chooses one of the options. In the health and disease survey project (10), which screened the mental health status of individuals over 15 years of age, including both literate and illiterate participants, and showed a prevalence of $21 \%$ with symptoms of mental disorders, the GHQ-28 questionnaire was filled out by interviewers. It seems that asking individuals questions about their mental health status in order to screen them for symptoms of mental disorders can affect their responses because many people do not want to talk openly to others about their mental problems.

Additionally, our higher prevalence may be due to specific age, economic, social and cultural conditions. Young people may experience intense psychological stress and be psychologically vulnerable for various reasons, including physical and sexual development, strong emotions, their search for an identity, fear of responsibility, and worries about going to university or choosing a job. Students, more than anyone else, need social acceptance and support, and when the appropriate conditions and amenities are not available, their mental and physical health can be damaged (17).

In the subscales of the questionnaire, the highest susceptibility scores were for symptoms of anxiety, depression, social impairment and somatic complaints (hypochondriasis) respectively.Anxiety was the most common symptom found in our students (39.8\%), followed by depression (33.1\%). Highest rates for anxiety were reported in other studies $(15,18)$. In the study on high-school students in Rafsanjan using the SCL-90-R questionnaire, anxiety disorders, with a prevalence of $8.4 \%$, were the most common mental disorder (15). In the study on students in Hamadan using the GHQ-28 test, anxiety (46.5\%) was the second most common mental

\begin{tabular}{lcccc}
\hline Table 3 Symptoms associated with mental disorders in high-school students in Khorramabad by sex & \\
Sex & Somatic complaints & Anxiety & Social impairment & Depression \\
& No. (\%) & No. (\%) & No. (\%) & No. (\%) \\
Male & $111(19.5)$ & $184(32.3)$ & $169(29.7)$ & $161(28.3)$ \\
Female & $188(29.7)$ & $303(47.9)$ & $221(34.9)$ & $237(37.4)$ \\
Total & $299(24.9)$ & $478(39.8)$ & $390(32.4)$ & $398(33.1)$ \\
P-valuvalue & $<0.001$ & $<0.001$ & 0.028 & $<0.001$ \\
${ }^{a}{ }^{a}$ Chi-squared test of independence. & & &
\end{tabular}




\begin{tabular}{|c|c|c|c|}
\hline Variable & Without symptoms & With symptoms & $P$-value \\
\hline \multirow[t]{2}{*}{ Age (years) [Mean (SD)] } & $16.15(0.86)$ & $16.07(0.89)$ & $0.144^{\mathrm{a}}$ \\
\hline & No. (\%) & No. $(\%)$ & \\
\hline Grade & & & 0.085 \\
\hline 1st (freshman) & $190(64.0)^{c}$ & $107(36.0)^{c}$ & \\
\hline 2nd (sophomore) & $274(56.4)$ & $212(43.6)$ & \\
\hline 3rd (junior) & $257(61.3)$ & $162(38.7)$ & \\
\hline Sex & & & $<0.001$ \\
\hline Male & $376(66.1)$ & $193(33.9)$ & \\
\hline Female & $345(54.5)$ & $288(45.5)$ & \\
\hline Academic stream & & & 0.013 \\
\hline General \& human sciences & $361(56.7)$ & $276(43.3)$ & \\
\hline Mathematical sciences & $157(60.2)$ & $104(39.8)$ & \\
\hline Empirical sciences & $203(66.8)$ & $101(33.2)$ & \\
\hline Type of school & & & 0.415 \\
\hline State & $478(59.2)$ & $330(40.8)$ & \\
\hline Nonprofit & $243(61.7)$ & $151(38.3)$ & \\
\hline Father's occupation & & & 0.008 \\
\hline Unemployed & $46(48.4)$ & $49(51.6)$ & \\
\hline White-collar worker & $315(62.5)$ & $189(37.5)$ & \\
\hline Manual labourer or farmer & $100(67.6)$ & $48(32.4)$ & \\
\hline Self-employed & $260(57.1)$ & $195(42.9)$ & \\
\hline Mother's occupation & & & 0.013 \\
\hline Housewife & $569(59.0)$ & $395(41.0)$ & \\
\hline White-collar worker & $102(71.3)$ & $41(28.7)$ & \\
\hline Manual labourer or farmer & $11(45.8)$ & $13(54.2)$ & \\
\hline Self-employed & $39(54.9)$ & $32(45.1)$ & \\
\hline Father's education & & & 0.033 \\
\hline Illiterate & $98(62.4)$ & $59(37.6)$ & \\
\hline Primary school or junior high school & $192(57.3)$ & $143(42.7)$ & \\
\hline High school & $223(56.3)$ & $173(43.7)$ & \\
\hline University & $208(66.2)$ & $106(33.8)$ & \\
\hline Mother's education & & & 0.339 \\
\hline Illiterate & $137(59.6)$ & $93(40.4)$ & \\
\hline Primary school or junior high school & $261(57.1)$ & $196(42.9)$ & \\
\hline High school & $230(62.2)$ & $140(37.8)$ & \\
\hline University & $93(64.1)$ & $52(35.9)$ & \\
\hline
\end{tabular}

${ }^{a}$ Independent $t$-test was used for age, but in other cases, the chi-squared test was used. SD = standard deviation.

problem after social impairment (49.5\%) (11).

In our study, no significant relationships were found between age and symptoms associated with hypochondriasis, anxiety, depression, and social impairment $(P=0.62)$. However, the study in Kashan on people over 18 years (9), the meta-analysis of the mental status of Iranian university students (7), and the study on students in Hamadan, all using the GHQ-28 test, all reported a significant relationship between age and the mental health of the participants for each of these disorders, with their prevalence increasing with age.

Our study showed significant relationships between symptoms of mental disorders in the students and their gender, grade and parental occupation. Our results for gender are consistent with the results of the study by Basnet (18), which reported a prevalence of depression of $32.43 \%$ among female students versus $28.07 \%$ in male students (19). In the study in Rafsanjan, using the SCL-90-R questionnaire, the prevalence of symptoms associated with mental disorders was $21.6 \%$ among 


\begin{tabular}{|c|c|c|c|c|}
\hline Variable & $\mathbf{B}^{\mathbf{a}}$ & SE & $\begin{array}{l}\text { Odds ratio } \\
\text { (95\% CI) }\end{array}$ & P-value \\
\hline Age & -0.285 & 0.167 & $0.75(0.54-1.04)$ & 0.087 \\
\hline Grade & & & & $<0.001$ \\
\hline 1st (freshman) & Reference & & & \\
\hline 2nd (sophomore) & 0.875 & 0.252 & $2.40(1.46-3.93)$ & 0.001 \\
\hline 3rd (junior) & 0.936 & 0.393 & $2.55(1.18-5.51)$ & 0.017 \\
\hline Sex & & & & $<0.001$ \\
\hline Male & Reference & & & \\
\hline Female & 0.456 & 0.127 & $1.58(1.23-2.02)$ & $<0.001$ \\
\hline FAcademi Academic stream & & & & 0.002 \\
\hline General and human sciences ${ }^{\mathrm{b}}$ & Reference & & & \\
\hline Mathematical sciences & -0.331 & 0.174 & $0.72(0.51-1.01)$ & 0.057 \\
\hline Empirical sciences & -0.612 & 0.170 & $0.54(0.39-0.76)$ & $<0.001$ \\
\hline Father's occupation & & & & 0.012 \\
\hline Unemployed & Reference & & & \\
\hline Government employee & -0.530 & 0.251 & $0.59(0.36-0.96)$ & 0.035 \\
\hline Manual labourer or farmer & -0.907 & 0.280 & $0.40(0.23-0.70)$ & 0.001 \\
\hline Self-employed & -0.443 & 0.238 & $0.64(0.40-1.02)$ & 0.063 \\
\hline Mother's occupation & & & & 0.023 \\
\hline Housewife & Reference & & & \\
\hline Government employee & -0.679 & 0.265 & $0.51(0.30-0.85)$ & 0.010 \\
\hline Manual labourer or farmer & 0.498 & 0.459 & $1.65(0.67-4.05)$ & 0.278 \\
\hline Self-employed & 0.236 & 0.269 & $1.27(0.75-2.14)$ & 0.379 \\
\hline
\end{tabular}

${ }^{a}$ Estimated regression coefficient.

${ }^{b}$ General and human sciences were combined to avoid multicollinearity in data modeling, since all students in the first year of high school are in the general academic stream. At the same time, merging these 2 categories led to better distinction between the streams for prevalence of mental disorders.

$S E=$ standard error of $B ; C I=$ confidence interval.

females and 10.6\% among males (15). A similar result was found in Kashan using the GHQ-28 questionnaire - the prevalence of suspected of mental disorders was 35.5\% among women and $21.2 \%$ among men (9). Furthermore, the national epidemiological survey reported a prevalence of suspected of mental disorders of $14.34 \%$ among women and $7.34 \%$ among men (16). These results emphasize the higher susceptibility of females to symptoms of mental disorders (20). The higher susceptibility of girls compared with boys could be because of biological factors, the role of gender, environmental stress, limited sources of satisfaction, and limitations on social participation of girls in the society. Female high-school students tend to consider this period of their lives (puberty as a developmental stage) very stressful, which may be due to inadequate and inappropriate education on the issues related to pubertal health, incorrect sources of information which may provide unhelpful and possibly erroneous information, and hormonal factors. In addition, fear of the future, marriage and educational failure, and their social role and the current traditions and culture of the society are environmental stressors which may increase the susceptibility of female high-school students to symptoms associated with mental disorders.

We found no significant relationship between susceptibility to symptoms of mental disorders and parental education. Other studies using the GHQ-28 test also did not show any significant relationship between maternal education and mental health symptoms $(7,21)$.

However, parental occupation was significantly associated with symptoms of mental disorders in our study: students whose fathers were government employees, manual labourers and farmers were less susceptible to symptoms of mental disorders than those with unemployed fathers. Moreover, susceptibility to mental disorders was significantly lower among the students whose mothers were government employees compared with those whose mothers were housewives. A study in Maku, Islamic Republic of Iran, using the GHQ28 test, reported a significant difference in the rate of mental health problems between students with employed and non-employed mothers: students with non-working mothers experienced more mental disorders than those with working mothers (22). The reason may lie in the fact that the working mothers had at least a bachelor's university degree; higher maternal education can affect 
the communication of mothers with their children and their mental health.

Our results revealed a significant relationship between susceptibility to symptoms of mental disorders and education (academic stream): students in empirical sciences and mathematical sciences were less likely to have symptoms of mental disorders than those in the general and human sciences stream. Students studying empirical sciences and mathematical sciences tend to have better job prospects in the future because more job opportunities will be available to them, and this could affect students' mental health status.

\section{Conclusions}

Our study shows that many adolescents are predisposed to developing mental disorders, including anxiety, depression, disorders of social functioning and somatic complaints (hypochondriasis). Health and education authorities need to consider starting counselling centres in schools to offer psychiatric counselling services, implementing regular mental health training programmes for school staff, students and parents, and including materials on mental health in school textbooks. It is recommended that qualitative studies be conducted to investigate this issue more thoroughly.

\section{Acknowledgement}

The authors would like to thank the Research Council of Lorestan University of Medical Sciences for their financial support.

Funding: This study was supported in part by grant C1184 from the Research Council of Lorestan University of Medical Sciences.

Competing interests: None declared.

\section{Facteurs associés à l'état de santé mentale d'élèves du secondaire à la République islamique d'Iran \\ Résumé}

Contexte : Les troubles mentaux apparaissant à l'âge adulte trouvent parfois leur origine dans des troubles de l'enfant et de l'adolescent. Il est donc important d'accorder une attention particulière à la santé mentale des jeunes.

Objectifs : Notre objectif était de déterminer l'état de santé mentale d'élèves du secondaire à Khorramabad (République islamique d'Iran) ainsi que les facteurs pouvant l'influencer.

Méthodes : La présente étude transversale incluait 1202 élèves du secondaire de Khorramabad au cours de l'année scolaire 2015-2016. Les élèves ont été sélectionnés à l'aide de la méthode d'échantillonnage aléatoire en grappes stratifié et à plusieurs degrés. Des données ont été recueillies sur les caractéristiques sociodémographiques des élèves, et le questionnaire général sur la santé en 28 items (GHQ-28) a été utilisé pour évaluer les symptômes des troubles mentaux. On a recouru à l'analyse de régression logistique pour mesurer la relation entre la présence de symptômes de troubles mentaux et les caractéristiques sociodémographiques.

Résultats : L'âge moyen des élèves était 16,1 ans (ET 0,9) et 52,7 \% étaient des filles. Au total, 481 (40\%) élèves (34 \% de garçons et $46 \%$ de filles) présentaient des symptômes de troubles mentaux. La plupart avaient des symptômes bénins, et $5 \%$ des symptômes graves. Des symptômes d'anxiété, de dépression et de déficience sociale étaient observés pour $40 \%$, $33 \%$ et $32 \%$ des élèves respectivement. Un nombre de filles considérablement plus élevé présentait ces symptômes $(p<$ 0,05 ). Les élèves de sexe féminin, de classes supérieures et ceux dont les pères étaient au chômage et les mères femmes au foyer étaient significativement plus susceptibles de présenter des symptômes de troubles mentaux $(p<0,05)$.

Conclusions : Cette étude a révélé une prévalence élevée de symptômes associés à des troubles mentaux chez les adolescents à Khorramabad. Des centres de conseil sont requis dans les écoles afin d'offrir des services de conseils psychiatriques aux élèves et de mettre en place des programmes réguliers de formation en santé mentale.

$$
\begin{aligned}
& \text { العوامل المرتبطة بالصحة النفسية لطلاب المدارس العليا في جمهورية إيران الإسلامية }
\end{aligned}
$$

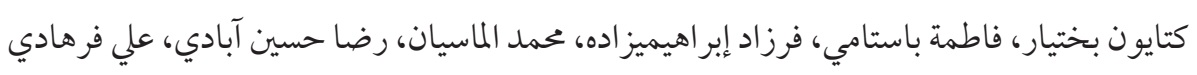

$$
\begin{aligned}
& \text { الخنالاصة }
\end{aligned}
$$

$$
\begin{aligned}
& \text { الخلفية: يمكن اقتفاء أثر الاضطر ابات النفسية بين البالغين من مرحلة الطفولة واضطر ابات اليافعين، مما يؤكد ضرورة الاهتحام بالصحة النفسية } \\
& \text { للشباب. } \\
& \text { الأهداف: هدفْنا من هذه الدراسة إلى الوقوف على حالة الصحة النفسية لطلاب المدارس العليا في خُرَمَ آباد، بجمهورية إير ان الإسلامية، والعوامل } \\
& \text { التي تؤثر عليها. }
\end{aligned}
$$

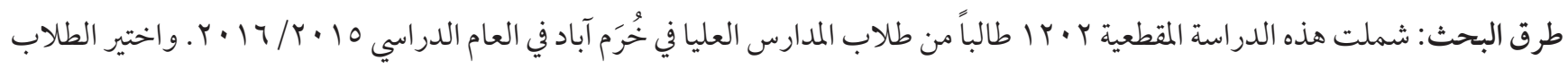




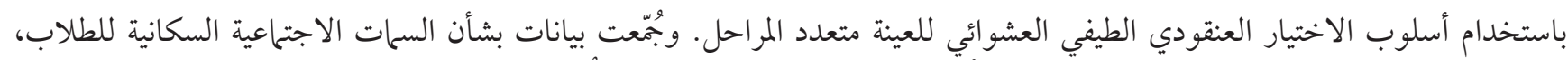

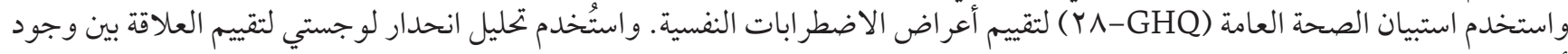
أعراض الاضطر اب النفسي والسمة العات الاجتماعية السكانية.

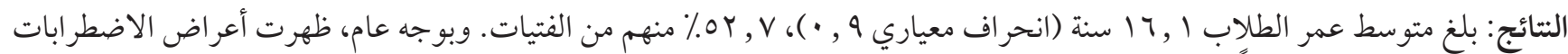

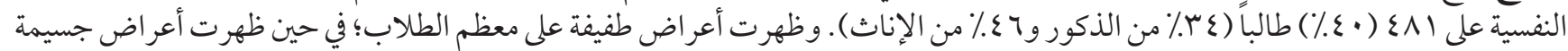

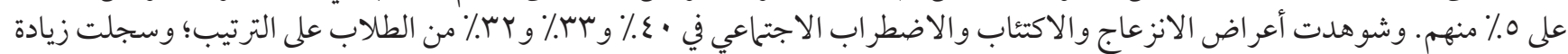

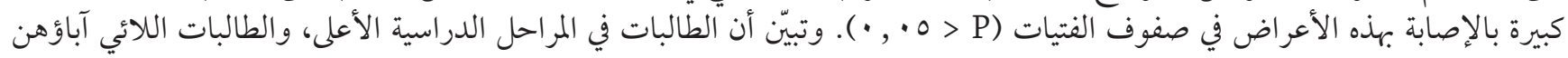

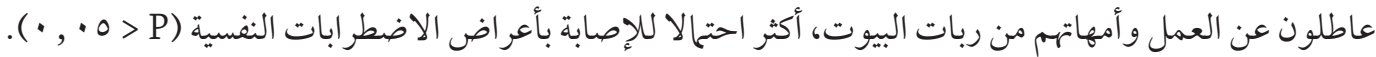

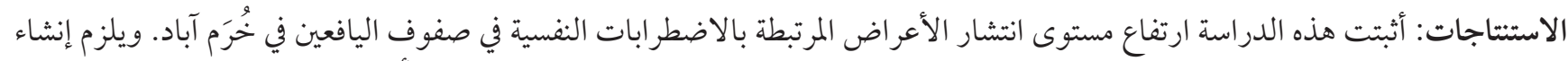

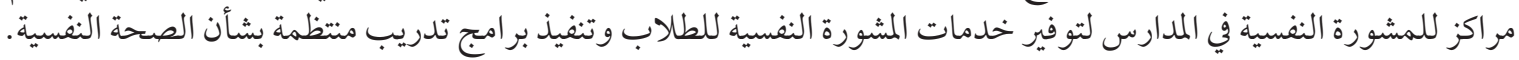

\section{References}

1. Atlas: child, adolescent and maternal mental health resources in the Eastern Mediterranean Region. Cairo: World Health Organization, Regional Office for the Eastern Mediterranean; 2011 (EMRO Technical Publications Series; 39).

2. Roberts RE, Attkisson CC, Rosenblatt A. Prevalence of psychopathology among children and adolescents. Am J Psychiatry. 1998 Jun;155(6):715-25. PMID:9619142

3. Khosravi S. [Epidemiology of mental disorders in urban and rural populations over 15 years in the city of Borujen]. J Shahrekord Univ Med Sci. 2002;4(4):31-9 [In Farsi].

4. Rostam Zadeh Z, Khaleelzadeh R. [Prevalence of depression among high school students in Urmia]. J Urmia Nursing and Midwifery Faculty. 2005;5(2):12-8 [In Farsi].

5. Hoseini H, Mosavi A. [Mental health status of newly admitted students of Mazandaran University of medical sciences in 19992000 academic year]. J Mazandran University of Medical Sciences. 2000;10(28):23-32 [In Farsi].

6. Yosefi F, Erfani N, Kheyrabadi GR, Ghanei H. [Prevalence of Conduct Disorder in a Group of Secondary School Students of Kordestan Province]. Iranian J Psychiatry \& Clinical Psychology. 2001;6(2):48-54 [In Farsi].

7. Zare N, Parvareh M, Nouri B, Namdari M. Mental health status of Iranian university students using the GHQ-28: a meta-analysis. Scientific Journal of Kurdistan University of Medical Sciences. 2016;21(4):1-16.

8. Soltanian A, Bahreeni F, Namazi S, Amiri M, Ghaedi H, Kohan GR. Mental health of high school students and its effective factors in Bushehr Province. Iranian South Med J. 2005;7(2):173-82.

9. Ahmadvand A, Sepehrmanesh Z, Ghoreishi FS, Afshinmajd S. Prevalence of psychiatric disorders in the general population of Kashan, Iran. Arch Iran Med. 2012 Apr;15(4):205-9. PMID:22424036

10. Noorbala A. National plan of health survey in Iran. Tehran: Ministry of Health and Medical Education; 2000.

11. 11. Sadeghian E, Moghadari Kosha M, Gorj S. [Study of the mental health status of high school female students in Hamadan]. J Hamedan University of Medical Sciences. 2010;17(3):39-45 [In Farsi].

12. 12. Shariati M, Kaffashi A, Ghalehbandi M, Fateh A, Ebadi M. Mental health in medical students of the Iran University of Medical Sciences. Payesh. 2002;1(3):29-37.

13. 13. Nazifi M, Mokarami H, Akbaritabar A, Faraji Kujerdi M, Tabrizi R, et al. [Reliability, validity and factor structure of the Persian translation of General Health Questionnaire (GHQ-28) in hospitals of Kerman University of Medical Sciences]. Journal of Fasa University of Medical Sciences/Majallah-i Danishgah-i Ulum-i Pizishki-i Fasa. 2014;3(4) [in Farsi].

14. Mousavi-Moghadam S, Tavan H, Sayehmiri K, Nadery S. [General health status of male and female students in junior schools of Ilam City in 2012]. Scientific Journal of Ilam University of Medical Sciences. 2014;22(2):57-65 [In Farsi].

15. Hosseini Fard SM, Birashk B, Atef Vahid MK. [Prevalance of mental disorder high school students in Rafsanjan city]. IJPCP. 2005; 11(1):71-80 [In Farsi].

16. Mohammadi M-R, Davidian H, Noorbala AA, Malekafzali H, Naghavi HR, Pouretemad HR, et al. An epidemiological survey of psychiatric disorders in Iran. Clin Pract Epidemol Ment Health. 200509 26;1(1):16. https://doi.org/10.1186/1745-0179-1-16 PMID:16185355

17. Yao YS, Kang YW, Jin YL, Gong WZ, Chen Y, Zheng L, et al. [A prevalence survey on the mental health of left behind adolescent in Anhui province]. Zhonghua Liu Xing Bing Xue Za Zhi. 2010 Dec;31(12):1359-62. PMID:21223664 [in Chinese].

18. Tao L, Zhang Q, Du S, Guo J, Liu Weijia, Pan H, et al. [Study on the psychological health condition among junior and senior high school students in Beijing, Shanghai and Guangzhou]. Wei Sheng Yan Jiu. 2015 Jan;44(1):57-9, 63. PMID:25958637 [In Chinese].

19. Basnet B, Jaiswal M, Adhikari B, Shyangwa PM. Depression among undergraduate medical students. Kathmandu Univ Med J (KUMJ). 2012 Jul-Sep;10(39):56-9. PMID:23434964

20. Gamwell K, Nylocks M, Cross D, Bradley B, Norrholm SD, Jovanovic T. Fear conditioned responses and PTSD symptoms in 
children: Sex differences in fear-related symptoms. Dev Psychobiol. 2015 Nov;57(7):799-808. https://doi.org/10.1002/dev.21313 PMID:26011240

21. Hosseini Sh, Mousavi S, Rezazadeh H. Assessment of mental health in students of junior high schools in the city of Sari, Iran. Quarterly Journal of Fundamentals of Mental Health. 2003;5(19-20):92-9.

22. Bakhtari Aghdam F, Ahmadzadeh S, HassanAlizadeh Z, Ebrahimi F, Sabzmakan L, Javadivala Z. The effect of maternal employment on the elementary and junior high school students' mental health in Maku. Glob J Health Sci. 201502 24;7(2):379-85. https://doi.org/10.5539/gjhs.v7n2p379 PMID:25716412 